\title{
Role of melatonin in modulation of oxidative stress induced by delta- aminolevulinic acid in adult male albino rats.
}

\author{
El-Sawi, MR, Badawy, ME and El-Gharieb, NM. \\ Zoology Department, Faculty of Science, Mansoura University.
}

\begin{abstract}
Backgrounds: Delta-aminolevulinic acid (ALA) is a heme precursor that accumulates in acute intermittent porphyria (AIP) due to enzymatic deficiencies in the heme biosynthetic pathway, its accumulation has been associated with several symptoms because it works as an endogenous source of reactive oxygen species, which can exert oxidative damage to cell structures. The present work was designed to examine the ability of melatonin, a well known antioxidant and a free radical scavenger secreted from the pineal gland, to revert ALA-promoted damage in brain, liver and kidney of rats.

Results: The present data demonstrated that chronically ALA-treated rats $(40 \mathrm{mg} / \mathrm{kg}$ body wt day after day for 14 days) exhibited very highly significant increases in malondialdehyde (MDA) and protein carbonyl (PC) whereas the level of glutathione (GSH) was significantly diminished in the tissue homogenates of all tested organs (brain, kidney \& liver). Among antioxidant enzymes, superoxide dismutase (SOD), catalase (CAT), glutathione reductase (GSH-Rd), glutathione-S-transferase (GST) activities were significantly diminished by ALA treatment. Intraperitoneal injection of melatonin $(10 \mathrm{mg} / \mathrm{kg}$ body weight, every day for 14 consecutive days) significantly ameliorated all the tested parameters. Melatonin moderately increased SOD, CAT, GSH-Rd and GST activities, thereby counteracting the oxidative stress induced by ALA. Nevertheless, exogenous ALA caused a strong net rise in MDA and PC and a significant decrease in GSH when given together with ALA, melatonin antagonized these effects and largely protected the integrity of tissue structures.

From the present data, the protection of melatonin against ALA oxidative stress is obviously, so it is well recommended to use melatonin in patients suffering from symptoms related to ALA accumulation.

Key words: Delta-aminolevulinic acid, oxidative stress, melatonin, malondialdehyde, protein carbonyl, glutathione, superoxide dismutase, catalase, glutathione-reductase, glutathione-S-transferase.
\end{abstract}

\section{Introduction}

ALA is the first metabolite of the biosynthetic pathway of the heme group. It accumulates in the blood and other tissues; mainly the liver and brain of patients with hereditary porphyria (e.g., acute intermittent porphyria) and acquired porphyria (e.g., lead poisoning porphyria), where it triggers serious tissue and neurological damage (Bechara et al., 2006).

ALA dehydratase (ALA-D) is an essential enzyme for all aerobic organisms because it participates in the biosynthetic pathway of tetrapyrrole molecules, which constitute prosthetic groups of physiologically important proteins such as hemoglobin and cytochromes (Jaffe et al., 1995 and Sassa, 1998). ALA-D is a sulfhydryl-containing enzyme; consequently, its activity is highly sensitive to the presence of prooxidant element, which can oxidize its -SH groups (Barbosa et al., 1998 and Soares et al., 2003). Inhibition of ALAD activity leads to an accumulation of ALA which undergoes auto-oxidation inducing free radicals and in this way induced lipid peroxidation (Hermes-lima et al., 1991). AIP is an inherited disease, characterized by a prophobilinogen deaminase deficiency and, as a consequence, accumulation of ALA, primarily in the liver (Kappas et al., 1983).

Pervious studies have shown, both in vitro and in vivo that ALA by it self is a pro-oxidant (Monteiro et al., 1989 and Neal 
et al., 1997). ALA is moreover able to mobilize iron from firritin and so is assumed to promote its auto-oxidation (Demasi et al., 1996). Over production and accumulation of ALA, as it occurs in AIP, can be the origin of an endogenous source of ROS, which can then exert their oxidative damage to cell structure (Princ et al., 1997). This precursor of heme rapidly undergoes enolization and subsequently aerobic oxidation at $\mathrm{pH} 7.0-8.0$ with the formation of reactive oxygen species such as hydrogen peroxide $\left(\mathrm{H}_{2} \mathrm{O}_{2}\right)$ and free radicals including the superoxide anion radical $\left(\mathrm{O}_{2}^{-}\right)$and hydroxyl radical $(\mathrm{OH})$, as well as the ALA enoyl radical (ALA) (Monteiro et al., 1989). Accumulation of ALA and porphobilinogen (PBG) in cellular fluid and tissues of ALA patients has long been known to be closely related with clinical symptoms (Gorchein, 1984).

Melatonin is a ubiquitously direct acting free radical scavenger and an indirect antioxidant (Pablos et al., 1997; Reiter et al., 2000). While being highly efficient in detoxifying the devastatingly reactive hydroxyl radical ( OH) (Tan et al., 1993; Qi et al., 2000), melatonin also directly interacts with single oxygen $\left({ }^{1} \mathrm{O}_{2}\right)$, peroxynitrite anion $\left(\mathrm{ONOO}^{-}\right)$(El-Sawi, 2003) and nitric oxide (NO) (Reiter et al., 1999). A single molecule of melatonin neutralizes two $(\mathrm{OH})$, the product of this interaction is cyclic 3-hydroxymelatonin (Tan et al., 1998). Melatonin was found to detoxify $\mathrm{H}_{2} \mathrm{O}_{2}$; the precursor of $(\mathrm{OH})$ (Tan et al., 2000). Melatonin exhibits several obvious advantages over classical antioxidants in terms of neuronal protection. First, melatonin possesses unique pharmacokinetic properties and is both lipophilic and, to a lesser degree, hydrophilic (Shida et al, 1994; Costa et al., 1997). Second, melatonin crosses the blood brain barriers with ease and distributes to all subcellular compartments including the membranes (Ceraulo et al., 1999), cytosol, mitochondria (Martin et al., 2000) and nucleus (Menendez-Pelaez et al., 1993). This makes melatonin available for on-site protection against attack by free radicals at multiple sites.

The aim of the present study was to examine the effects of melatonin on the activation of antioxidant enzymes and reduction of basic markers of oxidative stress MDA and PC induced by accumulation of ALA in an experimental model of porphyria.

\section{Material and Methods}

\section{Chemicals}

Melatonin and $\delta$-aminolevulinic acid were purchased from Sigma Chemical Company, ST. Louis, MO, USA. .All other chemicals and reagents were of analytical grade.

\section{Animals}

Adult male albino rats weighing 200 gram were kept under good ventilation, natural lighting (14 hrs light/10 hrs dark) and adequate stable diet. Food was withdrawn $18 \mathrm{hrs}$ before starting the experiment, while water was available $a d$ libitum.

\section{Experimental protocol}

The rats were divided randomly into four groups; six rats for each. The first group served as control and received an intraper-itoneal injection of physiological saline $(0.9 \% \mathrm{NaCl})$. The second group was given intraperitoneal injections of melatonin (dissolved in a solution of $0.9 \%$ $\mathrm{NaCl}$ and ethanol; 20/1, vol/vol) at a dose of $10 \mathrm{mg} / \mathrm{kg}$ body weight every day for 14 consecutive days. The third group was given interperi-toneal injections of ALA dissolved in $0.9 \% \mathrm{NaCl}$ at a dose of 40 $\mathrm{mg} / \mathrm{kg}$ body weight of ALA day after day for 14 days. The fourth group was received intraperitoneal injections of melatonin at a dose of $10 \mathrm{mg} / \mathrm{kg}$ body weight every day for 14 consecutive days as well as intraperitoneal injections of ALA at a dose of $40 \mathrm{mg} / \mathrm{kg}$ body weight day after day for 14 days. All substances were dissolved in a final volume of $0.5 \mathrm{ml} /$ injection.

\section{Sampling and tissue extraction}

At the end of the experimentation period, over night fasted rats were sacrificed using a sharp razor blade, Blood samples were collected in clean nonheparinized centrifuge tubes, then the tubes were let to stand for $15 \mathrm{~min}$ at $30^{\circ} \mathrm{C}$ after which the tubes were centrifuged at 3000 rpm for 15 min. Blood sera were carefully 


\section{El-Sawi, MR et al}

separated. Aliquots of each sample are labeled and kept at $-20^{\circ} \mathrm{C}$ for subsequent analysis.

Thereafter, brain, liver and kidney specimens were quickly removed, weighed and then homogenized in cold distilled water to form $10 \%(\mathrm{w} / \mathrm{v})$ homogenate. After labeling the samples, they were kept at $20^{\circ} \mathrm{C}$ for later different biochemical determinations.

\section{Methods}

MDA was assayed by the method of Ohkawa et al. (1979) while PC was estimated using method of Smith et al. (1991). GSH was determined according to the method of Prins and Loose (1969). The activity of SOD was determined by using the method of Nishikimi et al. (1972). CAT activity was detected by the method of Bock et al. (1980). GST was assayed according to the method of Habig et al. (1974). GSH-Rd was estimated according to the method of Beutler (1975). Finally, tissue protein was determined according to the method of Bradford 1976.

\section{Statistical analysis}

The data were statistically analyzed using one-way analysis of variance (ANOVA) followed by Tukey's method for pair wise multiple comparisons. Results are expressed as the mean \pm S.E. for six measures. Significance was considered at a level of $\mathrm{P}<0.05$.

\section{Results}

Administration of ALA increased lipid peroxidation (LPO) levels as indicated by the increase in MDA in brain, kidney and liver homogenates versus those of control or melatonin-injected rats (Table 1). These increases were significant $(\mathrm{p}<0.001)$.
When melatonin was given with ALA it significantly reduced $(\mathrm{p}<0.001) \quad$ MDA levels in brain and liver homogenates almost to the level of control rats, whereas MDA level in kidney homogenate still significantly higher $(\mathrm{p}<0.5)$ than that of the control rats.

As shown in table (2), intraperitoneal injection of ALA showed significant increases $(p<0.001)$ in PC concentration in brain, kidney and liver when compared with control rats. On the other hand, cotreatment of melatonin with ALA significantly improved the concentration of PC when compared with control rats. However, the level still significantly higher (PC) than that of control rats.

The results related to the changes in GSH content in rat brain, kidney and liver are presented in table (3). In case of rats injected with ALA; GSH levels were significantly diminished $(\mathrm{p}<0.001)$ than those of control or melatonin-injected rats. When melatonin was given to animals injected with ALA, the decrease in GSH levels was significantly improved.

In comparison to the control group, the activities of SOD, CAT, GST and GSH$\mathrm{Rd}$ were significantly lowered $(\mathrm{P}<0.001)$ in ALA injected group (Tables 4, 5, 6 and 7). Whereas, administration of melatonin to rats injected with ALA was shown to significantly improve the activities of SOD, CAT, GST to be near the normal level while the reduction in GSH-Rd activities in both brain and liver homogenates was found to be ameliorated to reach the control level. Conversely, in the kidney, the reduction in GSH-Rd activity did not improve completely. Additionally, there were no significant effects for all tested parameters in melatonin administration on the animals of the control group. 
Table (1): Brain, kidney and liver malondialdehyde (MDA) level (nM/mg wet tissue) of different rat groups.

\begin{tabular}{|c|c|c|c|c|}
\hline Parameter & Control & Melatonin & ALA & ALA + Melatonin \\
\hline Brain & $193.9 \pm 0.73$ & $193.7 \pm 1.14$ & $528.1 \pm 1.04 * * *$ & $201.3 \pm 3.87^{\circ \circ \circ}$ \\
\hline Kidney & $141.2 \pm 0.76$ & $139 . .8 \pm 0.83$ & $421.3 \pm 0.83^{* * *}$ & $151.7 \pm 4.57^{*} \circ{ }^{\circ \circ}$ \\
\hline Liver & $117 . .9 \pm 3.57$ & $117.8 \pm 3.42$ & $433.5 \pm 1.90^{* * *}$ & $128 . .8 \pm 1.54^{\circ 0 \circ}$ \\
\hline
\end{tabular}

Values are mean of 6 animals \pm SE; values with asterisk (s) are statistically

(* = significant at $\mathrm{P}<0.05, * * *=$ significant at $\mathrm{P}<0.001)$ different from control or melatonin-injected rats. Whereas, values with circles are statistically

$\left({ }^{\circ}=\right.$ significant at $\left.\mathrm{P}<0.001\right)$ different from ALA-injected rats.

Table (2): Brain, kidney and liver protein carbonyl (PC) content ( $\mu \mathrm{M} / \mathrm{g}$ wet tissue) of different rat groups.

\begin{tabular}{|c|c|c|c|c|}
\hline Parameter & Control & Melatonin & ALA & ALA + Melatonin \\
\hline Brain & $3.73 \pm 0.15$ & $3.60 \pm 0.15$ & $6.91 \pm 0.16^{* * * *}$ & $4.45 \pm 0.14^{* * \circ \circ \circ}$ \\
\hline Kidney & $3.75 \pm 0.15$ & $3.36 \pm 0.14$ & $7.60 \pm 0.24 * * *$ & $4.80 \pm 0.15^{* * \circ \circ \circ}$ \\
\hline Liver & $1.28 \pm 0.02$ & $1.03 \pm 0.02$ & $6.83 \pm 0.33^{* * * *}$ & $2.00 \pm 0.06 * * \circ \circ$ \\
\hline
\end{tabular}

Values are mean of 6 animals \pm SE; values with asterisks are statistically

$\left(* *=\right.$ significant at $\mathrm{P}<0.01,{ }^{* * *}=$ significant at $\left.\mathrm{P}<0.001\right)$ different from control or melatonin injected group. Whereas, values with circles are statistically

$\left({ }^{\circ \circ}=\right.$ significant at $\left.\mathrm{P}<0.001\right)$ different from ALA-injected rats.

Table (3): Brain, kidney and liver glutathione (GSH) content (mg GSH/g wet tissue) of different rat groups.

\begin{tabular}{|c|c|c|c|c|}
\hline Parameter & Control & Melatonin & ALA & ALA + Melatonin \\
\hline Brain & $1.63 \pm 0.14$ & $1.68 \pm 0.10$ & $0.49 \pm 0.02 * * *$ & $1.18 \pm 0.06 * \circ \circ \circ$ \\
\hline Kidney & $0.35 \pm 0.02$ & $0.36 \pm 0.02$ & $0.06 \pm 0.007 * * *$ & $0.25 \pm 0.003 * \circ \circ \circ$ \\
\hline Liver & $1.23 \pm 0.02$ & $1.33 \pm 0.03$ & $0.39 \pm 0.01 * * *$ & $0.99 \pm 0.02 * \circ \circ \circ$ \\
\hline
\end{tabular}

Values are mean of 6 animals \pm SE; values with asterisk (s) are statistically

(* = significant at $\mathrm{P}<0.05, * * *=$ significant at $\mathrm{P}<0.001)$ different from control or melatonin-injected rats. Whereas, values with circles are statistically

$\left({ }^{\circ \circ}=\right.$ significant at $\left.\mathrm{P}<0.001\right)$ different from ALA-injected rats.

Table (4): Brain, kidney and liver Superoxide dismutase (SOD) activity (U/g wet tissue) of different rat groups.

\begin{tabular}{|c|c|c|c|c|}
\hline Parameter & Control & Melatonin & ALA & ALA + Melatonin \\
\hline Brain & $142.8 \pm 0.90$ & $146.9 \pm 1.52$ & $98.2 \pm 1.73 * * *$ & $133.1 \pm 3.38 * 0 \circ 0$ \\
\hline Kidney & $166.6 \pm 0.91$ & $170.4 \pm 1.21$ & $121 \pm 1.18 * * *$ & $155.1 \pm 4.31 * 000$ \\
\hline Liver & $176 \pm 1.83$ & $177.1 \pm 1.96$ & $121.2 \pm 1.22 * * *$ & $164.1 \pm 4.09 * \circ \circ \circ$ \\
\hline
\end{tabular}

Values are mean of 6 animals \pm SE; values with asterisk (s) are statistically

( $^{*}=$ significant at $\mathrm{P}<0.05, * * *=$ significant at $\left.\mathrm{P}<0.001\right)$ different from control or melatonin-injected rats. Whereas, values with circles are statistically

$\left({ }^{\circ \circ}=\right.$ significant at $\left.\mathrm{P}<0.001\right)$ different from ALA-injected rats. 
Table (5): Brain, kidney and liver catalase (CAT) activity $\left(\mu \mathrm{M} \mathrm{H}_{2} \mathrm{O}_{2} / \mathrm{Sec} / \mathrm{g}\right.$ wet tissue) of different rat groups.

\begin{tabular}{|c|c|c|c|c|}
\hline Parameter & Control & Melatonin & ALA & ALA + Melatonin \\
\hline Brain & $35.0 \pm 1.85$ & $36.5 \pm 2.00$ & $7.48 \pm 1.31^{* * *}$ & $7.48 \pm 1.76^{* \circ \circ \circ}$ \\
\hline Kidney & $41.8 \pm 0.51$ & $42.5 \pm 0.66$ & $11.91 \pm 0.60^{* * * *}$ & $36.1 \pm 0.66^{*} \circ \circ \circ$ \\
\hline Liver & $36.1 \pm 0.18$ & $37.8 \pm 0.24$ & $9.85 \pm 0.68^{* * *}$ & $31.6 \pm 0.57 * \circ \circ \circ$ \\
\hline
\end{tabular}

Values are mean of 6 animals \pm SE; values with asterisk (s) are statistically

$(*=$ significant at $\mathrm{P}<0.05, * * *=$ significant at $\mathrm{P}<0.001)$ different from control or melatonin-injected rats. Whereas, values with circles are statistically

$\left({ }^{\circ}=\right.$ significant at $\left.\mathrm{P}<0.001\right)$ different from ALA-injected rats.

Table (6): Brain, kidney and liver glutathion-S-Transferase (GST) activity ( $\mu M / g$ wet tissue) of different rat groups.

\begin{tabular}{|c|c|c|c|c|}
\hline Parameter & Control & Melatonin & ALA & ALA + Melatonin \\
\hline Brain & $5.00 \pm 0.29$ & $5.21 \pm 0.25$ & $2.05 \pm 0.31 * * *$ & $3.93 \pm 0.23 * * \circ \circ$ \\
\hline Kidney & $4.95 \pm 0.19$ & $5.21 \pm 0.08$ & $2.05 \pm 0.22 * * *$ & $3.70 \pm 0.53 * \circ \circ$ \\
\hline Liver & $5.83 \pm 0.23$ & $6.15 \pm 0.19$ & $1.76 \pm 0.13 * * *$ & $4.50 \pm 0.39 * * \circ \circ$ \\
\hline
\end{tabular}

Values are mean of 6 animals \pm SE; values with asterisk (s) are statistically

(* = significant at $\mathrm{P}<0.05, * *=$ significant at $\mathrm{P}<0.01$, *** = significant at $\mathrm{P}<0.001)$ different from control or melatonin-injected rats. Whereas, values with circles are statistically $\left({ }^{\circ}=\right.$ significant at $\mathrm{P}<0.01,{ }^{\circ}=$ significant at $\mathrm{P}<0.001)$ different from ALA-injected rats.

Table (7): Brain, kidney and liver glutathione reductase (GSH-Rd) (U/mg different rat groups.

protein) of

\begin{tabular}{|c|c|c|c|c|}
\hline Parameter & Control & Melatonin & ALA & ALA + Melatonin \\
\hline Brain & $38.7 \pm 0.98$ & $40.9 \pm 1.28$ & $24.95 \pm 2.37^{* * *}$ & $36.7 \pm 1.47^{\circ 00}$ \\
\hline Kidney & $34.4 \pm 1.15$ & $36.8 \pm 1.49$ & $21.41 \pm 1.94^{* * *}$ & $29.9 \pm 1.02^{* *}$ ०00 \\
\hline Liver & $38.7 \pm 0.98$ & $40.9 \pm 1.28$ & $24.95 \pm 2.37^{* * *}$ & $36.7 \pm 1.47^{\circ 00}$ \\
\hline
\end{tabular}

Values are mean of 6 animals \pm SE; values with asterisks are statistically

$(* *=$ significant at $\mathrm{P}<0.01, * * *=$ significant at $\mathrm{P}<0.001)$ different from control. Whereas, values with circles are statistically $\left({ }^{\circ \circ}=\right.$ significant at $\left.\mathrm{P}<0.001\right)$ different from ALA-injected rats.

\section{Discussion}

Injection of ALA usually results in a blood concentration of approximately 20-30 $\mu \mathrm{g} / \mathrm{ml}$ after $30 \mathrm{~min}$ which is maintained for up to $24 \mathrm{hrs}$ and is similar in magnitude to the level observed in patients with prophyrias (Mc Gillion et al., 1975). After a single injection of ALA, a rapid uptake by a variety of tissues is observed with the highest concentration occurring in the liver. Thus, multiple injections with ALA at a dose of $40 \mathrm{mg} / \mathrm{kg}$ body weight, as applied in the current study, are believed to mimic the conditions of AIP or the other disturbances related to ALA accumulation (Karbownik et al., 2000)

The present results showed that multiple injections of ALA to rats caused significant increases $(\mathrm{P}<0.001)$ in $\mathrm{MDA}$ and PC levels compared to control or melatonin-injected rats. Similar changes were already observed in different experimental situations designed by Karbownik et al. (2000); Weis et al. (2003); Noriega et al. (2003) for MDA as well as Lelli et al. (2005) for MDA and PC. They concluded that MDA is a sufficiently precise marker of oxidative stress and they attributed this increase in MDA due to the nature of ALA as aprooxidant which when produced in excess or accumulated, it works as an endo-genous source of toxic oxygen derivatives, such as $\mathrm{OH}, \mathrm{O}_{2}{ }^{-}$and $\mathrm{H}_{2} \mathrm{O}_{2}$ (Monteiro et al., 1989 and HermesLima et al., 1991). 
Additionally, administration of melato-nin concomitantly with ALA led to a signifi-cant decrease in MDA formation as well as a decrease in PC. These results are in agreement with that obtained by Carneiro and Reiter (1998), they demonstrated that melatonin administration significantly decreased LPO in liver and kidney of rats. And also with other findings obtained by many authors worked on different experimental models. For MDA, Princ et al. (1998) in rat cerebellum and Juknat et al. (2003) in mouse astrocytes. Tan et al. (1994) explained how melatonin greatly inhi-bits MDA formation. Melatonin can scavenge free radicals and/or inhibit their formation, and additionally, melatonin per se can act by up-regulating endogenous antioxidant defenses. The protective effect of melatonin against oxidative damage induced by ALA treatment, as indicated by significant increases in the levels of MDA and PC, may relate to its lipophilic and hydrophilic properties (Reiter, 1998), its ability to localize in a superficial position in lipid bilayers near the polar heads of phospholipids (Ceraulo et al., 1999), its preventive actions against protein damage (Tesoriere et al., 1999) and to its ability to scavenge the initiating agents of LPO (Reiter et al., 2000).

Conversely, GSH content was signific-antly diminished in ALA injectedrats versus control rats. This finding was in agreement with these obtained by Neal et al. (1996) and Noriega et al. (2003). Meister (1994) reported that the GSH works as an antioxidant, and he attributed this property to the presence of numerous SH groups, which can react with the free radicals and products of lipid peroxidation such as lipid peroxides and aldehydes protecting in this way against development of oxidative stress (Tandon et al., 2002). Thus, it can supposed that the reduction in GSH after ALA injection might result from the utilization of $-\mathrm{SH}$ groups to scavenge free radicals formed (Jurczuk et al., 2006). Administration of melatonin was found to improve significantly GSH content. Urata et al. (1999) attributed this to the ability of melatonin to stimulate the synthesis of GSH.
In ALA injected rats significant reductions $(\mathrm{P}<0.001)$ in the activities of SOD, CAT, GST and GSH-Rd were observed. These results are in accordance with that obtained by Pereira et al. (1992) and Demasi et al. (1996) for SOD; TomasZapico et al. (2002) for SOD and GSH-Rd; Noriega et al. (2003) for SOD, CAT and glutathione peroxidase (GSH-Px), they attributed this presumably due to the vulnerability of their active centers to free radicals.

On the other hand, administration of melatonin with ALA was found to preserve SOD, CAT, GST and GSH-Rd activities arou-nd the normal values obtained in control group. Beside its ability to scavenge free radi-cals, melatonin stimulates a host of antiox-idative enzymes including SOD, GSH-Px and GSH-Rd, thereby further reduction in the oxidative state of cells has been achieved (Pablos et al., 1997; Reiter et al., 2000). SOD is considered as a major antioxidative enzyme, because it dismutases the superoxide anion $\left(\mathrm{O}_{2}^{-}\right)$radical to hydrogen peroxide $\left(\mathrm{H}_{2} \mathrm{O}_{2}\right)$ and reduces the formation of peroxynitrite. Antolin et al. (1996) indicated that melatonin increased the tissue mRNA levels for both manganese and copper SOD levels in animals treated with melatonin. Melatonin stimulates the activity of GSH-Px, which metabolizes $\mathrm{H}_{2} \mathrm{O}_{2}$ to water. In this process, GSH gets oxidized and forms oxidized glutathione (GSSG). The GSSG is reduced back to GSH in the presence of the enzyme GSH$\mathrm{Rd}$, the activity of which is also stimulated by melatonin (Pablos et al., 1997). Melatonin was found also to stimulate the activity of CAT, which is also involved in reducing the $\mathrm{H}_{2} \mathrm{O}_{2}$ and thus reduce the generation of hydroxyl radicals (Montilla $e t$ al., 1997).

\section{Conclusion}

Multiple injections of ALA to rats leads to significant increase in MDA and an increase in PC in brain, kidney and liver tissue homogenates, while significant decreases in GSH level and SOD, CAT, GST and GSH-Rd activities were registered which provide the evidence of oxidative stress. 
Melatonin has a prophylactic effect against oxidative stress incorporated with ALA accumulation. Thus, the administration of melatonin might be beneficial for AIP therapy.

\section{References}

1. Antolin I, Rodriguez C, Sainz RM, Mayo JC, Uria H, Kotler ML, Rodiguz-colunga MJ, Tolivia D and Menendez-Pelaez A (1996): Neurohormone melatonin prevents cell damage: Effect on gene expression for antioxidant enzymes. FASEB J., 10: 882890.

2. Barbosa NB, Rocha JB, Zeni G, Emanuelli T, Beque MC and Braga, $\mathrm{AL}$ (1998): Effect of organic forms of selenium on delta-aminolevulinate dehydratase from liver, kidney, and brain of adult rats. Toxicology and Applied Pharmacology, 149(2): 243-53.

3. Bechara EJ, Dutra F, Cardoso ES, Sartori A, Olympio KP, panatti, CA, Adhikari A and Assuncão NA (2006): The dual face of endogenous $\alpha$ aminoketones: Pro-oxidizing metabolic weapons. Comparative Biochemi-stry and Physiology Part C: Toxicology \& Pharmacology. (Article in press, available on line 14 July 2006, at SienceDirect.com)

4. Beutler E (1975): Red cell metabolism: Manual of biochemical methods. 2nd edition, publ. Grune and Stration, New York, pp., 69-70.

5. Bock PP, Karmer $\mathbf{R}$ and Pavelka $M$ (1980): A simple assay for catalase determination. Cell Biol. Monogr., 7: 44-47.

6. Bradford MM (1976): A rapid and sensitive method for the quantification of microgram quantities of protein utilizing the principle of protein dye binding. Anal. Biochem., 7: 248-254.

7. Carneiro RC and Reiter RJ (1998): Delta-aminolevulinic acid-induced lipid peroxidation in rat kidney and liver is attenuated by melatonin: An in vitro and in vivo study. J. Pineal Res., 24(3): 131-6.

8. Ceraulo L, Ferrugia M, Tesoriere L, Segreto S, Livrea MA and Livert VT (1999): Interactions of melatonin with membrane models: Portioning of melatonin in AOT and lecithin reversed micelles. J. Pineal Res., 26:108-112.

9. Costa EJ, Shida CS, Biaggi MH, Ito AS and Lamy-Freund MT (1997): How melatonin interacts with lipid bilayers: A study by fluorescence and ESR spectroscopies. FEBS Lett., 416: 103-106.
10. Demasi M, Penatti CA, Delucia $R$ and Bechara EJ (1996): The prooxidant effect of 5-aminolevulinic acid in the brain tissue of rats: Implication in neuropsychiatric manifest-ations in porphyrias. Free Radic. Biol. Med., 20(3): 291-9.

11. El-Sawi MR (2003): Inhibition of peroxynitrite-induced lipid peroxidation in rat liver microsomes by glutathione, melatonin and trolex. Egypt. J. Zool., 40: 345-356.

12. Gorchein A (1984): Determination of delta-aminolaevulinic acid in biological fluids by gas-liquid chromatography with electron-capture detection. Biochem. J., 219(3): 883-9.

13. Habig WH, Pabst MJ and Jakoby WB (1974): Glutathione-S-transferase the first enzyme step in mercapturic acid formation. J. Biol. Chem., 1 (24a): 7150-7139.

14. Hermes-Lima M, Valle VG, Vercesi AE and Bechara EJ (1991): Damage to rat liver mitochondria promoted by deltaaminolevulinic acid-generated reactive oxygen species: Connections with acute intermittent porphyria and lead poisoning. Biochem. Biophys. Acta., 1056:57-63.

15. Jaffe EK, Shafinaz A, Mitchell LW, Taylor KM, Volin M and Markham GD (1995): Characterization of the role of the stimulatory magnesium of Escherichia coli porphobil-inogen synthase, Biochem., 34, 244-251.

16. Juknat AA, Kotler ML, Quaglino A, Carrillo NM and Hevor T (2003): Necrotic cell death induced by $\delta$ aminolevulinic acid in mouse astrocytes. Protective role of melatonin and other antioxidants. J. Pineal Res., 35 (1): 1-11.

17. Jurczuk $\mathbf{M}$, Moniuszko-Jakoniuk $\mathbf{J}$ and Brzoska M (2006): Involvement of some low-molecular thiols in the peroxidative mechanisms of lead and ethanol action on rat liver and kidney. Toxicology, 219 (issue, 1-3):11-21.

18. Kappas $A$ and Sassa $S$ (1983): Hereditary tyrosinemia and the heme biosynthetic pathway. Profound inhibition of deltaaminolevulinic acid dehydratase activity by succinyl acetone. The journal of clinical investigation, 71(3): 625-34.

19. Karbownik M, Tan DX, Manchester LC and Reiter RJ (2000): Renal toxicity of the carcinogen $\delta$-aminolevulinic acid: antioxidant effects of melatonin. Cancer Lett., 161(1): 1-7.

20. Lelli SM, San Martin de Viale LC and Mazzetti MB (2005): Response of glucose metabolism enzymes in an acute prophyria model: Role of reactive oxygen species. Toxicol., 216 (1): 49-58 
21. Martin M, Macias M, Escames G, Leon J and Acuna-Castroviejo D (2000): Melatonin but not vitamins $\mathrm{C}$ and $\mathrm{E}$ maintains glutathione homeostasis in $\mathrm{t}$ butyl hydroperoxide-induced mitochondrial oxidative stress. FASEB. J., 14: 2128-2130.

22. McGillion FB, Thompson GG and Goldberg A (1975): Tissue uptake $\delta$ aminolevulinic acid. Biochem. Pharmacol., 24: 229-301.

23. Meister A (1994): Glutathione, ascorbate and cellular protection. Cancer Res., 54:1969s-1965s.

24. Menendez-Pelaez A, Poeggeler B, Reiter RJ, Barlow-Walden L, Pablos MI and Tan DX (1993): Nuclear localization of melatonin in different mammalian tissues: Immunocytoch-emical and radioimmunoassay evidence. J. Cell. Biochem., 53: 373- 382.

25. Monteiro HP, Abdalla DS and Monteiro HM (1989): Free radical generation during delta-aminolevulinic acid autoxidation: Induct-ion by hemoglobin and connections with porphyrinpathies. Arch. Biochem. Physic., 271: 206-16.

26. Montilla P, Tunez I, Munoz MC, Soria JV and Lopez A (1997): Antioxidative effect of melatonin in rat brain oxidative stress induced by adriamycin. Rev. Esp. Fisiol., 53: 301-305.

27. Neal R, Yang P, Fiechtl J, Yildiz D, Gurer H and Ercal N (1997): Pro-oxidant effects of delta-aminolevulinic acid (deltaALA) on Chinese hamster ovary (CHO) cells. Toxicology letters, 91(3): 169-78.

28. Nishikimi M, Rao N and Yagi K (1972): The occurrence of superoxide anion in the reaction of reduced phyenazine methosulphate and molecular oxygen. Biochem. Biophys. Res. Commun., 46: 844-853.

29. Noriega GO, Tomaro ML and Batle AM (2003): Bilirubin is highly effective in preventing in vivo $\delta$-aminolevulinic acidinduced oxidative cell damage. Biochimica et Biophysica Acta (BBA)., 1638(2): 173178.

30. Ohkawa H, Ohishi N and Yagi K (1979): Assay for lipid peroxides in animal tissues by thiobarbituric acid reaction. Anal. Biochem., 95: 351-358.

31. Pablos MI, Guerrero JM, Ortiz GG, Agapito MT and Reiter RJ (1997): Both melatonin and a putative nuclear melatonin receptor agonist CGP 52608 stimulate glutathione peroxidase and glutathione reductase activities in mouse brain in vivo. Neuroendocrinol. Lett., 18: 49-58.

32. Pereira B, Curi R, Kokubun E and Bechara EJ (1992): 5-aminolevulinic acid- induced alternations of oxidative metabolism in sedentary and exercise-trained rats. J. Appl. Physiol., 72(1): 226-30.

33. Princ FG, Jukanat AA, Maxit AG, Cardalda C and Battle A (1997): Melatonin's antioxidant protection against $\delta$-aminolevulinic acid-induced oxidative damage in rat cerebellum. Pineal Res., 23(1): 40-6.

34. Princ FG, Juknat AA, Amitrano AA and Batlle A (1998): Effect of reactive oxygen species promoted by delta-aminolevulinic acid on porphyrin biosynthesis and glucose uptake in rat cerebellum. Gen. Pharmacol., 31(1): 143-8.

35. Prins HK and Loose JA (1969): Glutathione "Chapter 4" in biochemical methods in red cell genetic. Edited by Yunis JJ Academic Press, N. Y. D. London, pp: 126-129.

36. Qi W, Reiter RJ, Tan DX, Manchester LC, Siu AW and Garcia JJ (2000): Increased levels of oxidatively damaged DNA induced by chromium (IV) and $\mathrm{H}_{2} \mathrm{O}_{2}$ : Protection by melatonin and related molecules. J. Pineal Res., 29: 54-61.

37. Reiter RJ (1998): Oxidative damage in the central nervous system: Protection by melatonin. Prog. Neurobiol., 56(3): 359-84.

38. Reiter RJ, Tan DX, Acuna CD, Burkhardt $S$ and Karbownik $M$ (2000): Melatonin: Mechanism and actions as an antioxidant. Curr. Topics Biophys., 24: 171-183.

39. Reiter RJ, Tan DX, Cabrera J and D'Arpa D (1999): Melatonin and tryptophan derivati-ves as free radical scavengers and antioxidants. Adv. Exp. Med. Biol., 467: 379-387.

40. Sassa S, Gross U, Jacob K, Deybach JC, Nordmann Y, Frank M and Doss MO (1998): 5-Aminolevulinic acid dehydratase deficiency porphyria: A twenty-year clinical and biochemical follow-up. Clin. Chem., 44(9): 1892-6.

41. Shida CS, Castrucci AM and LamyFreund MT (1994): High melatonin solubility in aqueous medium. J. Pineal Res., 16: 198-201.

42. Smith CD, Carney JM, Starke-Reed PE, Oliver CN, Stadtman ER, Floyd RA and Markesbery WR (1991): Excess brain protein oxidation and enzyme dysfunction in normal aging and in Alzheimer disease. Proc. Natl. Acad. Sci., USA, 88: 1054010543.

43. Soares FA, Nogueira CW, Nascimento PC, Muller D and Rocha JB (2003): 2,3Dimercaptopropane-1-sulfonic acid and meso-2,3-dimercaptosuccinic acid increase 


\section{El-Sawi, MR et al}

mercury- and cadmium-induced inhibition of delta-aminolevulinate dehydratase. Toxicol., 184(2-3): 85-95.

44. Tan DX, Chen LD, Poeggeler B, Manchester LC and Reiter RJ (1993): Melatonin: A potent endogenous hydroxyl radical scavenger. Endocr. J., 1: 57-60.

45. Tan DX, Manchester LC, Reiter RJ, Plummer BF, Hardies LJ, Weintraub ST and Vijayaxmi AS (1998): A novel melatonin metabolite, cyclic 3-hydroxy melatonin: A biomarker of in vivo, hydroxyl radical generation. Biochem. Biophys. Res. Commun., 253: 614-620.

46. Tan DX, Manchester LC, Reiter RJ, Plummer BF, Linson J, Weintraub ST and Qi W (2000): Melatonin directly scavenges hydrogen peroxide: A potentially new metabolic pathway of melatonin biotransform-ation. Free Radic. Biol. Med., 29: 1177-1185.

47. Tan DX, Reiter RJ, Chen LD, Poeggeler B, Manchester LC and Barlow-Walden RL (1994): Both physiological and pharmacol-ogical levels of melatonin reduce DNA adduct formation induced by carcinogen safrole. Carcinogenesis, 15: 215-218.
48. Tandon SK, Singh S, Prasad S and Siddiqui MK (2002): Reversal of leadinduced oxidative stress by chelating agent, antioxidant, or their combination in the rats. Environ. Res., Section (A) 90:61-6.

49. Tesoriere L, D'Arpa D, Conti S, Giacone V, Pintandi AM and Livrea MA (1999): Melatonin protects human red blood cells from oxidative hemolysis: New insight into the radical-scavenging activity. J. Pineal Res., 27: 95-105.

50. Tomas-Zapico C, Coto-Montes A, Martinez-Fraga J, Rodriguez-Colunga MJ, Hardeland R and Tyolivia D (2002): Effect of $\delta$-aminolevulinic acid and melatonin in the harderian gland of femal Syrian hamsters. Free Radic. Biol. Med., 23(11): 1197-1204.

51. Urata Y, Honma S, Goto S, Todoroki S, Iida T, Cho S, Honma $K$ and Kondo $T$ (1999): Melatonin induces $\gamma$-glutamylcysteine synthetase mediated by activator protein-I in human vascular endothelial cells. Free Radic. Biol. Med., 27: 838-847.

52. Weiss TS, Pahernik S, Scheruebi I, Jauch KW and Thasler WE (2003): Cellular damage to human hepatocytes through repeated application of 5-aminolevulinic acid. J Hepatol., 38(4): 476-82.

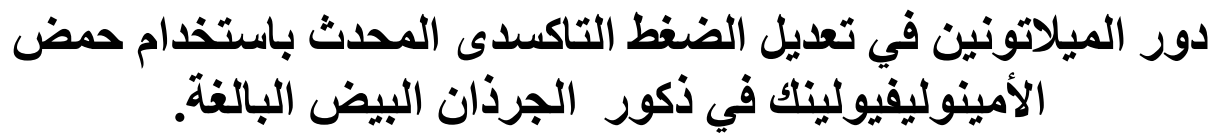


ممدوح رشاد فرج الصاوي، محيى الاين بدوى، نيرمين محمد الغريب العيب قسم علم الحيوان، كلية العلوم، جائن بامعة المنصورة فيرمين

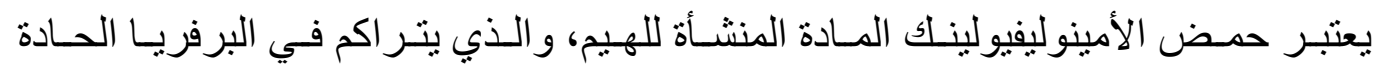

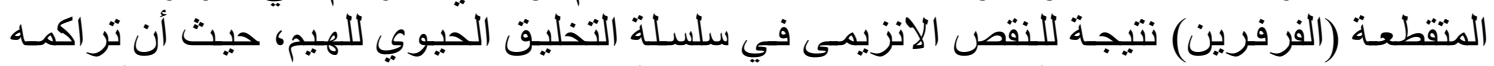

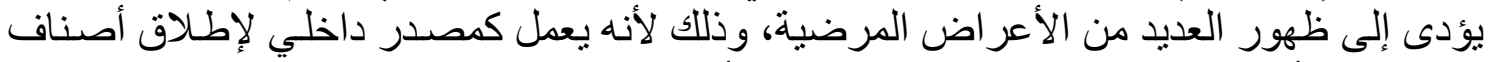

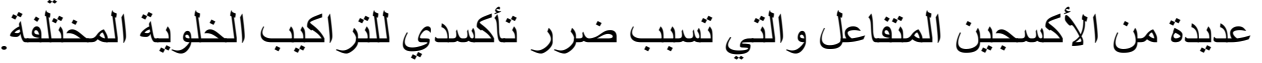

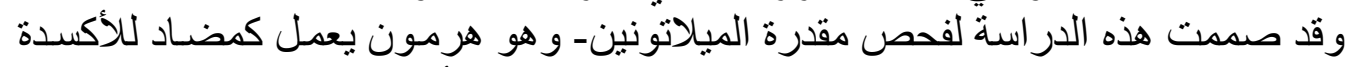

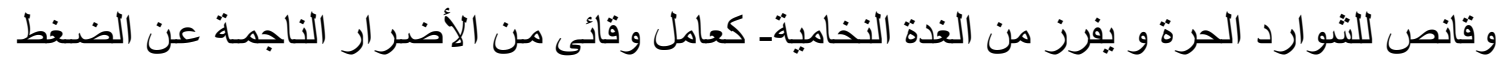

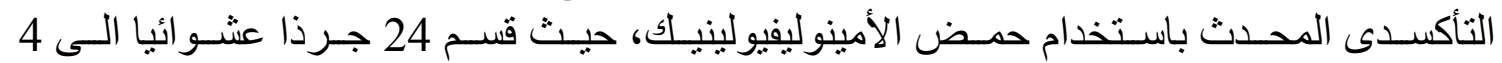

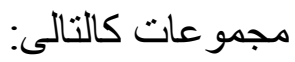
مجمو عة طبيعية ضابطة. مجمو عة معاملة بالميلاتونين بجرة عـة قدر ها 10 مجر/كجم من وزن الجسم في التجويف البريتونى لمدة 14 يوما متتاليا. مجمو عة معاملة بجر عات مزمنة من حمض الأمينو ليفيوليولينيك قدر ها 40مهج/كجم من وزن الجسم

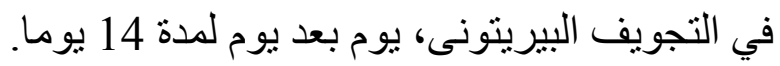

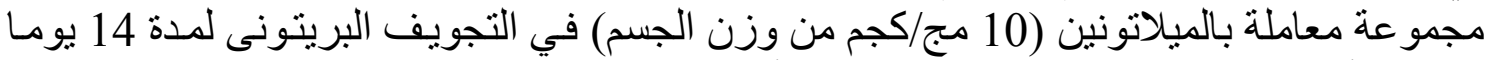

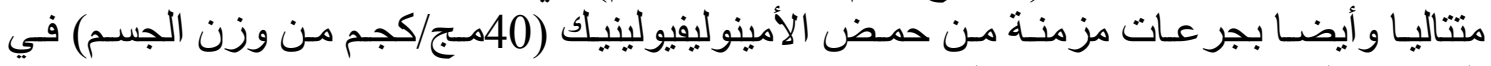

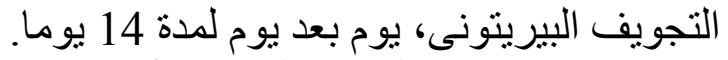

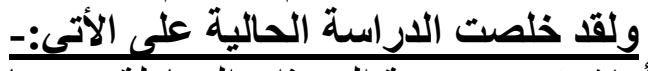

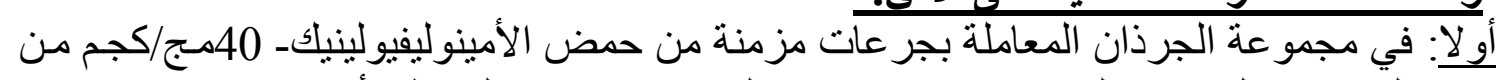

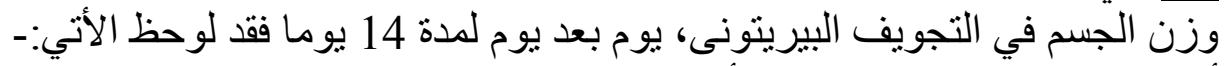

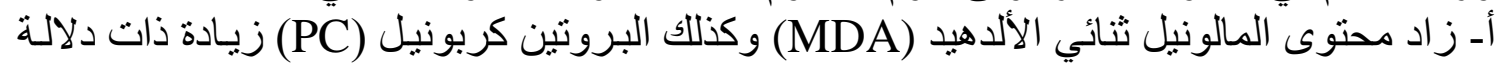

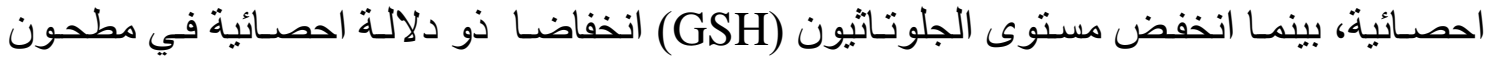

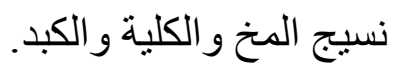

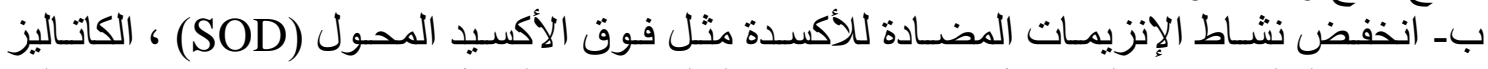

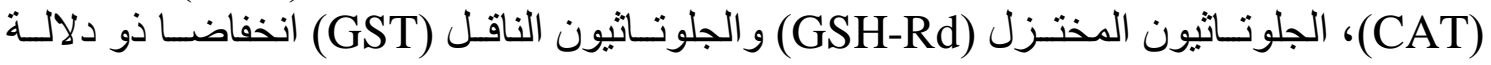
احصائية.

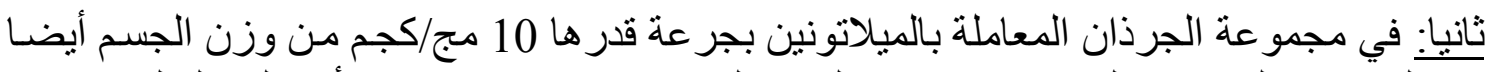

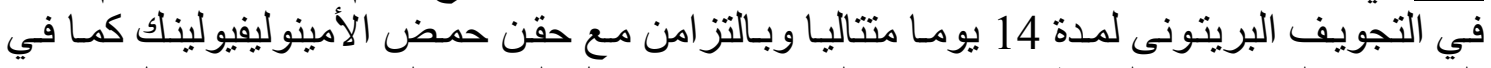

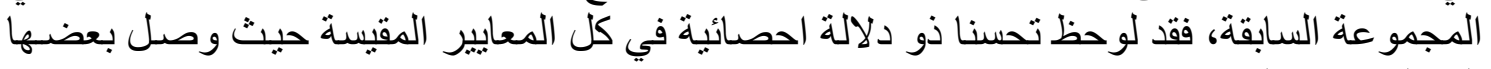
إلى المستوى الطبيعي.

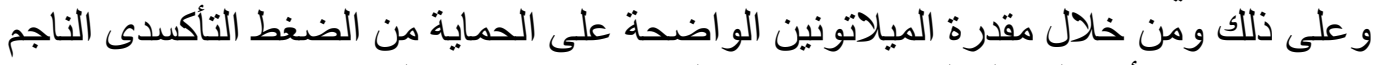

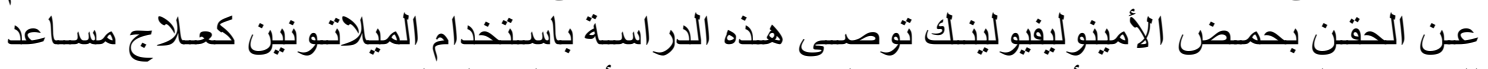

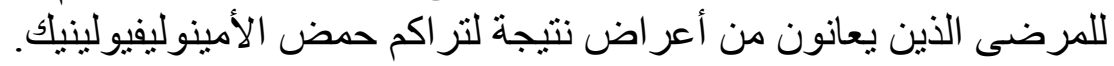

